\title{
Novel PITX2c loss-of-function mutations associated with complex congenital heart disease
}

\author{
DONG WEI ${ }^{1}$, XIAO-HUI GONG ${ }^{1}$, GANG QIU $^{1}$, JUAN WANG $^{2}$ and YI-QING YANG ${ }^{3}$ \\ ${ }^{1}$ Department of Neonatology, Shanghai Children's Hospital, Shanghai Jiao Tong University, \\ Shanghai 200040; ${ }^{2}$ Department of Cardiology, Tongji Hospital, Tongji University School of Medicine, \\ Shanghai 200065; ${ }^{3}$ Department of Cardiology, Cardiovascular Research Laboratory and Central Laboratory, \\ Shanghai Chest Hospital, Shanghai Jiao Tong University, Shanghai 200030, P.R. China
}

Received January 12, 2014; Accepted February 27, 2014

DOI: $10.3892 /$ ijmm.2014.1689

\begin{abstract}
Congenital heart disease (CHD) is the most common form of birth defect in humans and is the leading non-infectious cause of infant mortality. Emerging evidence strongly suggests that genetic risk factors play an important role in the pathogenesis of CHD. However, CHD is of pronounced genetic heterogeneity, and the genetic defects responsible for CHD in an overwhelming majority of patients remain unclear. In this study, the entire coding region and splice junction sites of the PITX2c gene, which encodes a paired-like homeodomain transcription factor crucial for proper cardiovascular morphogenesis, was sequenced in 170 unrelated neonates with CHD. The available relatives of the mutation carriers and 200 unrelated ethnically matched healthy individuals were genotyped. The disease-causing potential of the PITX2c sequence variations was predicted by MutationTaster and PolyPhen-2. The functional effect of the mutations was characterized using a luciferase reporter assay system. As a result, 2 novel heterozygous PITX2c mutations, p.R91Q and p.T129S, were identified in 2 unrelated newborns with transposition of the great arteries and ventricular septal defect, respectively. A genetic scan of the pedigrees revealed that each mutation co-segregated with CHD transmitted in an autosomal dominant pattern with complete penetrance. The mutations, which altered the amino acids completely conserved evolutionarily, were absent in 400 normal chromosomes and were predicted to be causative.
\end{abstract}

Correspondence to: Dr Gang Qiu, Department of Neonatology, Shanghai Children's Hospital, Shanghai Jiao Tong University, 1400 West Beijing Road, Shanghai 200040, P.R. China

E-mail: qiugang89@sina.cn

Dr Yi-Qing Yang, Department of Cardiology, Cardiovascular Research Laboratory and Central Laboratory, Shanghai Chest Hospital, Shanghai Jiao Tong University, 241 West Huaihai Road, Shanghai 200030, P.R. China

E-mail: yang99yang66@hotmail.com

Key words: neonate, congenital heart disease, genetics, transcription factor, PITX2c, reporter gene analysis
Functional analysis revealed that the PITX2c mutations were both associated with significantly diminished transcriptional activity compared with their wild-type counterpart. This study demonstrates the association between PITX2c loss-of-function mutations and the transposition of the great arteries and ventricular septal defect in humans, providing further insight into the molecular mechanisms responsible for CHD.

\section{Introduction}

Congenital heart disease (CHD), characterized by the developmental abnormality of the heart and intrathoracic great vessels, is the most common birth defect in humans worldwide, occurring in approximately $1 \%$ of live births, and is the major non-infectious cause of infant morbidity and mortality, accounting for approximately $30 \%$ of neonatal deaths resulting from developmental malformations (1). According to the specific anatomic lesions, CHD is categorized into at least 21 clinical types, encompassing atrial septal defect, ventricular septal defect, atrioventricular septal defect, tetraology of Fallot, patent ductus arteriosus, transposition of the great arteries, right ventricular outflow tract obstruction, aortic stenosis, pulmonary atresia, coronary artery deformation, tricuspid atresia, Ebstein's anomaly of the tricuspid valve, double outlet right ventricle, hypoplastic left heart syndrome, interrupted aortic arch and total anomalous pulmonary venous connection (1). If unrepaired, these cardiovascular deformations may contribute to poor exercise tolerance, degraded life quality, delayed fetal brain development, infective endocarditis, metabolic disorders, pulmonary hypertension, congestive heart failure, thromboembolic stroke, arrhythmias and even sudden cardiac death (2-13). Despite its high prevalence and important clinical significance, the etiology for CHD in an overwhelming majority of patients remains unclear.

In mammals, the heart is the first organ to form during embryogenesis (14). Cardiogenesis is a complex and dynamic biological process that requires the orchestration of cardiac cell commitment, differentiation, proliferation and migration, and both environmental and genetic risk factors may perturb this exquisite temporal and spatial cooperation, leading to a wide variety of CHD (15-22). A growing body of evidence underscores the key role of cardiac transcription factors in 
embryonic cardiovascular morphogenesis, and a long list of mutations in the genes coding for cardiac transcription factors, including the NK and GATA families, have been associated with CHD (23-41). However, CHD is a genetically heterogeneous disease and the genetic defects responsible for CHD in the majority of patients remain unknown.

Previous studies have indicated that the cardiac transcription factor, PITX2c, a member of the bicoid-like homeodomain family of transcription factors, is essential for normal cardiovascular development (42-49). The PITX2c gene is predominantly expressed in the embryonic and adult hearts, playing a crucial role in the embryogenesis of the left atrium, cardiac conduction system and pulmonary venous myocardium (50). In mice, targeted deletion of PITX2c has been shown to lead to embryonic lethality due to distinct types of CHD, including atrial isomerism, double-outlet right ventricle, atrial septal defect, ventricular septal defect, transposition of the great arteries, and abnormal aortic arch, as well as incomplete closure of the body wall (42). In humans, PITX2c mutations have been implicated in congenital atrial septal defect, ventricular septal defect, double outlet of the right ventricle and atrial fibrillation (51-54). These findings justify screening PITX $2 c$ in other cohorts of patients with CHD.

\section{Materials and methods}

Study subjects. A cohort of 170 unrelated neonates with CHD was recruited from the Chinese Han population. The available relatives of the mutation carriers were also included. The patients were evaluated by individual and familial histories, review of the medical records, complete physical examination, 12-lead electrocardiogram and 2-dimensional transthoracic echocardiography with a color flow Doppler. Transesophageal echocardiography and cardiac catheterization were performed in some patients. Most patients underwent cardiac surgery or catheter-based repair. The patients with known chromosomal abnormalities or syndromic cardiovascular defects were excluded from the study. Clinical investigations were carried out by cardiologists who had no knowledge of the genotype.

A total of 200 unrelated, ethnically matched healthy individuals randomly enlisted from the individuals undergoing routine physical examinations were used as the control subjects. According to the reviews of medical histories and analyses of the echocardiographic records, the control individuals had no CHD. The ethnic origin of a participant was ascertained by a combination of self-reported ethnicity and a personal questionnaire asking questions regarding birthplace, language, religion and ancestry.

Peripheral venous blood specimens from patients with CHD and control individuals were prepared. The study protocol was reviewed and approved by the local institutional ethics committee and written informed consent was obtained from the parents or guardians of the participants prior to enrollment in the study.

Genetic analysis of human PITX2c. Genomic DNA was extracted from the blood lymphocytes of each participant using the Wizard Genomic DNA Purification kit (Promega Corp. Madison, WI, USA). The PITX2c gene was sequenced initially in 170 unrelated neonates with CHD, and the genotyping of
PITX2c was subsequently performed in the available relatives of the mutation carriers and the 200 unrelated control individuals. The referential genomic DNA sequence of PITX2c was derived from GenBank (Accession no. NC_000004), which was at the National Center for Biotechnical Information (NCBI; http://www.ncbi.nlm.nih.gov/).

The primer pairs used to amplify all the coding exons and exon-intron boundaries of PITX2c by polymerase chain reaction (PCR) were designed as previously described (53). PCR was performed using HotStar Taq DNA Polymerase (Qiagen GmbH, Hilden, Germany) on a Veriti Thermal Cycler (Applied Biosystems, Foster, CA, USA), with standard conditions and concentrations of reagents. Amplified products were analyzed on $1 \%$ agarose gels stained with ethidium bromide and purified using the QIAquick Gel Extraction kit (Qiagen GmbH). Both strands of each PCR product were sequenced with a BigDye $^{\circledR}$ Terminator v3.1 Cycle Sequencing kit under an ABI PRISM 3130 XL DNA Analyzer (both from Applied Biosystems). The sequencing primers were the same as those used for the above-mentioned specific region amplification. The DNA sequences were viewed and analyzed with DNA Sequencing Analysis Software ${ }^{\circledR}$ v5.1 (Applied Biosystems). The variant was validated by re-sequencing an independent PCR-generated amplicon from the same subject. Additionally, for an identified sequence variant, the Exome Variant Server (EVS; http://evs.gs.washington.edu/EVS) and the NCBI single nucleotide polymorphism (SNP; http:/www.ncbi.nlm.nih.gov/ SNP) online databases were queried to confirm its novelty.

Alignment of multiple PITX2c protein sequences among species. Multiple PITX2c protein sequences across various species were aligned using the online program, MUSCLE, version 3.6 (http://www.ncbi.nlm.nih.gov/homologene?cmd=R etrieve\&dopt=MultipleAlignment\&list_uids=55454).

Prediction of the pathogenic potential of a PITX2c sequence variation. The disease-causing potential of a PITX2c sequence variation was predicted by MutationTaster (http://www.mutationtaster.org), which automatically yielded a probability for the variation to be either a pathogenic mutation or a benign polymorphism. Notably, the P-value used here is the probability of the correct prediction rather than the probability of error as used in t-test statistics (i.e., a value close to 1 indicates high accuracy of the prediction). Besides, another online program PolyPhen-2 (http://genetics.bwh.harvard.edu/pph2) was also utilized to evaluate the causative likeliness of a variant.

Expression plasmids and site-directed mutagenesis. The recombinant expression plasmid PITX2c-pcDNA4, which was constructed by Strungaru et al (55), was a gift from Professor Georges Christé, from Physiopathologie des troubles du rythme cardiaque, Faculté de Pharmacie de Lyon, Université Lyon 1, Lyon, France. The atrial natriuretic factor (ANF)-luciferase reporter plasmid, which contains the 2600-bp 5'-flanking region of the $A N F$ gene, namely $\mathrm{ANF}(-2600)-\mathrm{Luc}$, was kindly provided by Dr Ichiro Shiojima, from the Department of Cardiovascular Science and Medicine, Chiba University Graduate School of Medicine (Chiba, Japan). Each of the identified variations was introduced into wild-type PITX2c using a QuickChange II XL Site-Directed Mutagenesis kit 
(Stratagene, La Jolla, CA, USA) with a complementary pair of primers. The mutants were sequenced to confirm the desired mutations and to exclude any other sequence variations.

Luciferase reporter gene assay. Chinese hamster ovary $(\mathrm{CHO})$ cells were cultured in Dulbecco's modified Eagle's medium supplemented with $10 \%$ fetal calf serum, as well as $100 \mathrm{U} / \mathrm{ml}$ penicillin and $100 \mathrm{~g} / \mathrm{ml}$ streptomycin. The ANF(-2600)-Luc reporter construct and an internal control reporter plasmid, pGL4.75 (hRluc/CMV; Promega), were used in transient transfection assays to explore the transactivational activity of the PITX2c mutant. The CHO cells were transfected with $2 \mu \mathrm{g}$ of the wild-type PITX2c-pcDNA4 or mutant PITX2c-pcDNA4 (R91Q or T129S) or the empty vector pcDNA4, $2.0 \mu \mathrm{g}$ of ANF(-2600)-Luc reporter construct, and $0.04 \mu \mathrm{g}$ of pGL4.75 control reporter vector using Lipofectamine 2000 Transfection Reagent (Invitrogen, Carlsbad, CA, USA). For co-transfection experiments, $1 \mu \mathrm{g}$ of wild-type PITX2c-pcDNA4, $1 \mu \mathrm{g}$ of mutant PITX2c-pcDNA4 (R91Q or T129S), $2.0 \mu \mathrm{g}$ of ANF(-2600)-Luc, and $0.04 \mu \mathrm{g}$ of pGL4.75 were used. The transfected cells were incubated for $24 \mathrm{~h}$, then lysed and assayed for reporter activities. Firefly luciferase and Renilla luciferase activities were measured with the Dual-Glo luciferase assay system (Promega). The activity of the $A N F$ promoter was presented as fold activation of Firefly luciferase relative to Renilla luciferase. Three independent experiments were conducted at minimum for wild-type or mutant PITX2c.

Statistical analysis. Experimental data are expressed as the means \pm standard deviations. Continuous variables were tested for normality of distribution, and the Student's unpaired t-test was used for the comparison of numeric variables between 2 groups. A comparison of the categorical variables between 2 groups was performed using Pearson's $\chi^{2}$ test or Fisher's exact test where appropriate. A two-tailed P-value $<0.05$ was considered to indicate a statistically significant difference.

\section{Results}

Baseline characteristics of the study population. A cohort of 170 unrelated neonates with CHD was enrolled and clinically evaluated in contrast to a total of 200 unrelated, ethnicallymatched healthy individuals used as the controls. All the participants had no established environmental risk factors for CHD, such as maternal illness and drug use in the first trimester of pregnancy, parental smoking, and long-term exposure to toxicants and ionizing radiation. The baseline clinical characteristics of the 170 unrelated CHD patients are summarized in Table I.

PITX2c mutation. All the exons and splice junction sites of the PITX2c gene was sequenced in the 170 unrelated neonates with CHD, and 2 heterozygous sequence variations in PITX2c weree identified in 2 out of the 170 patients, with a mutational prevalence of approximately $1.18 \%$ based on the patient population. Specifically, a substitution of adenine for guanine at the second nucleotide of codon 91 of the PITX2c gene (c. $272 \mathrm{G}>\mathrm{A})$, predicting the transition of arginine into glutamine at amino acid 91 (p.R91Q), was identified in a neonate with transition of great arteries and ventricular septal
Table I. Baseline clinical characteristics of the 170 unrelated neonates with congenital heart disease.

\begin{tabular}{|c|c|c|}
\hline Parameter & $\begin{array}{c}\text { No. } \\
\text { or quantity }\end{array}$ & $\begin{array}{c}\text { Percentage } \\
\text { or range }\end{array}$ \\
\hline Male & 89 & 52.4 \\
\hline Age (days) & $12.6 \pm 8.5$ & $1-26$ \\
\hline Birth weight (kg) & $3.1 \pm 0.8$ & $1.6-5.5$ \\
\hline Positive family history & 51 & 30 \\
\hline \multicolumn{3}{|l|}{$\begin{array}{l}\text { Distribution of different } \\
\text { types of CHD }\end{array}$} \\
\hline Isolated CHD & 84 & 49.4 \\
\hline VSD & 21 & 12.4 \\
\hline PDA & 14 & 8.2 \\
\hline ASD & 10 & 5.9 \\
\hline PS & 9 & 5.3 \\
\hline TGA & 7 & 4.1 \\
\hline AVSD & 6 & 3.5 \\
\hline $\mathrm{COA}$ & 5 & 2.9 \\
\hline DORV & 5 & 2.9 \\
\hline PTA & 3 & 1.8 \\
\hline TAPVC & 2 & 1.2 \\
\hline HLHS & 1 & 0.6 \\
\hline PA & 1 & 0.6 \\
\hline Complex CHD & 86 & 50.6 \\
\hline TGA + VSD & 27 & 15.9 \\
\hline $\mathrm{TOF}$ & 15 & 8.8 \\
\hline $\mathrm{VSD}+\mathrm{PDA}$ & 12 & 7.1 \\
\hline $\mathrm{ASD}+\mathrm{VSD}$ & 9 & 5.3 \\
\hline $\mathrm{PDA}+\mathrm{TGA}$ & 5 & 2.9 \\
\hline VSD + DORV & 5 & 2.9 \\
\hline $\mathrm{ASD}+\mathrm{TGA}$ & 5 & 2.9 \\
\hline $\mathrm{ASD}+\mathrm{PDA}$ & 4 & 2.4 \\
\hline $\mathrm{ASD}+\mathrm{VSD}+\mathrm{DORV}$ & 2 & 1.2 \\
\hline $\mathrm{IAA}+\mathrm{VSD}$ & 1 & 0.6 \\
\hline $\mathrm{ASD}+\mathrm{VSD}+\mathrm{PDA}$ & 1 & 0.6 \\
\hline \multicolumn{3}{|l|}{ Treatment } \\
\hline Surgical repair & 110 & 64.7 \\
\hline Follow-up & 60 & 35.3 \\
\hline
\end{tabular}

CHD, congenital heart disease; VSD, ventricular septal defect; ASD, atrial septal defect; PDA, patent ductus arteriosus; PS, pulmonary stenosis; TGA, transposition of the great arteries; AVSD, atrioventricular septal defect; COA, coarctation of the aorta; DORV, double outlet right ventricle; PTA, persistent truncus arteriosus; TAPVC, total abnormal pulmonary venous connection; HLHS, hypoplastic left heart syndrome; PA, pulmonary atresia; TOF, tetralogy of Fallot; IAA, interruption of the aortic arch.

defect. A change of adenine into thymine at the first nucleotide of codon 129 of the PITX $2 c$ gene $(\mathrm{c} .385 \mathrm{~A}>\mathrm{T})$, equivalent to the transversion of threonine into serine at amino acid 129 (p.T129S), was detected in another newborn with transition of great arteries and ventricular septal defect. The sequence 


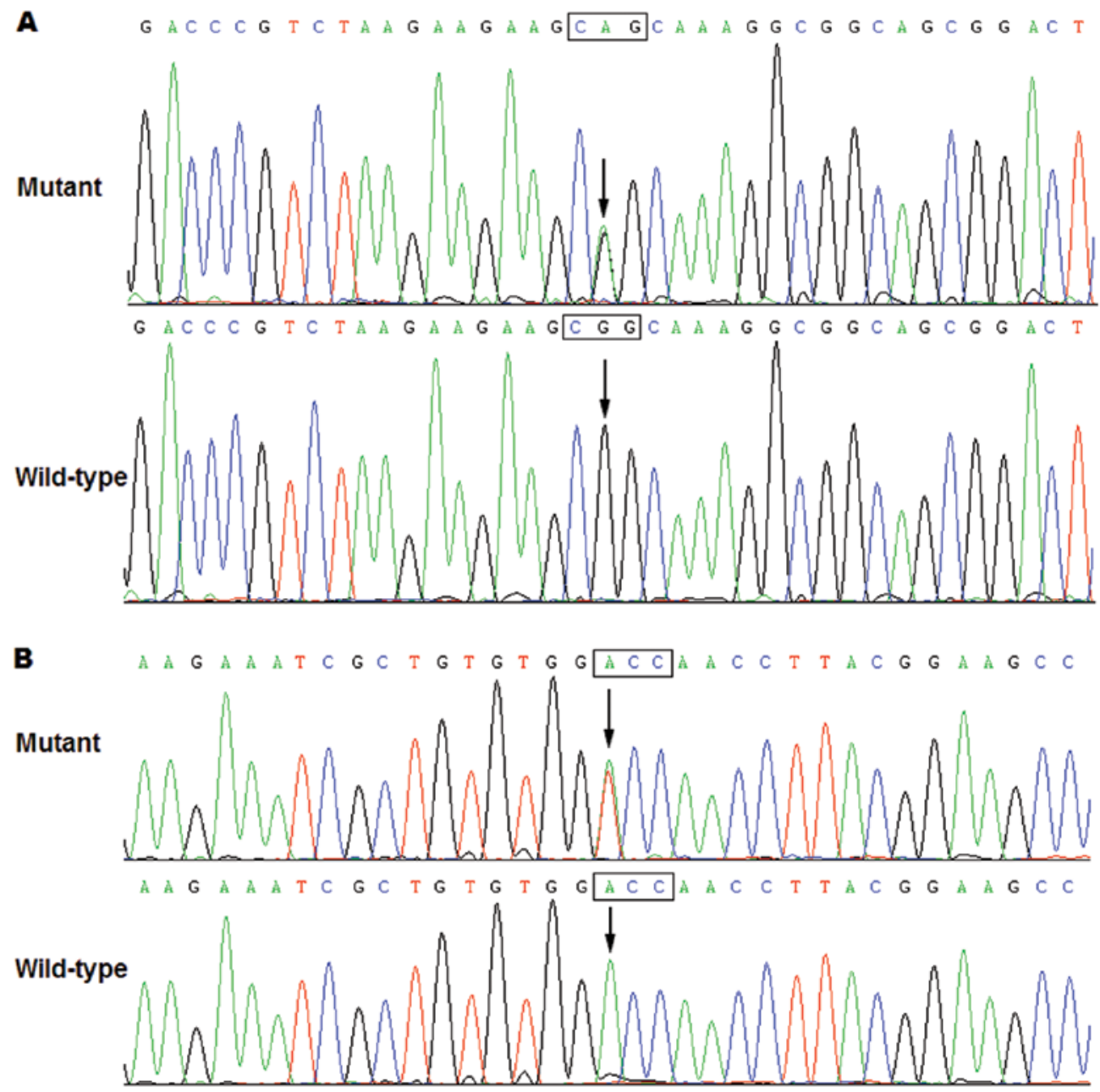

Figure 1. Sequence electropherograms of the PITX2c mutations in contrast to their controls. Arrows indicate the heterozygous nucleotides of G/A (A) and A/T (B) in the index patients from families 1 and 2, respectively (mutant), or the homozygous nucleotides of G/G (A) and A/A (B) in the corresponding control individuals (wild-type). The rectangle indicates the nucleotides constituting a codon of PITX2c.

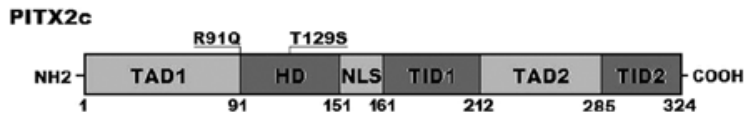

Figure 2. Schematic diagram of PITX2c protein structure with the identified mutations marked. The mutations identified in the patients with congenital heart disease are shown above the structural domains. NH2, amino-terminus; TAD1, transcriptional activation domain 1 (amino acids 1-90); HD, homeodomain (amino acids 91-151); NLS, nuclear localization signal (amino acids 145-161); TID1, transcriptional inhibitory domain 1 (amino acids 162-212); TAD2, transcriptional activation domain 2 (amino acids 213-285); TID2, transcriptional inhibitory domain 2 (amino acids 286-324); $\mathrm{COOH}$, carboxyl-terminus.

electropherograms showing the identified heterozygous PITX2c variations compared with the corresponding control sequences are shown in Fig. 1. A schematic diagram of PITX $2 c$ showing the structural domains $(56,57)$ and the locations of the detected mutations is presented in Fig. 2. The mutation was neither observed in 400 control chromosomes nor reported in the EVS and NCBI SNP databases, which were consulted again on January 12, 2014. A genetic scan of the available family members of the mutation carriers revealed that in each family the mutation was present in all affected family members alive, but absent in the unaffected family

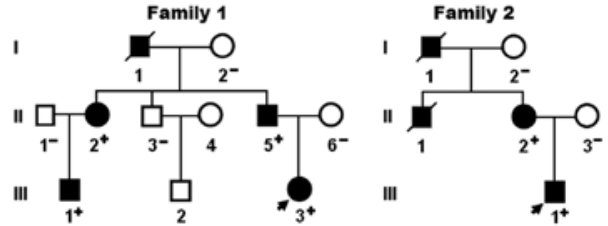

Figure 3. Pedigree structures of the families with congenital heart disease. Families are designated as family 1 and family 2, respectively. Family members are identified by generations and numbers. Square, male family member; circle, female member; closed symbol, affected member; open symbol, unaffected member; arrow, proband; symbol with a slash, deceased member; +, carrier of the heterozygous mutation; -, non-carrier.

members examined. An analysis of the pedigrees revealed that in each family, the mutation co-segregated with CHD transmitted as an autosomal dominant trait with complete penetrance. Atrial fibrillation was confirmed by the early electrocardiograms in patients I-1 and II-1 from family 1 . The pedigree structures of the families are shown in Fig. 3. The phenotypic characteristics and the results of genetic screening of the affected family members are listed in Table II.

Alignment of multiple PITX2c protein sequences. A crossspecies alignment of multiple PITX2c protein sequences 


\begin{tabular}{|c|c|c|c|c|c|}
\hline & 83 & 91 & & & $9 \mathbf{S}$ \\
\hline NP_000316.2 & AEDPSKKK & $R$ & QRRQRTHFTSQQLQELEATFQRNRYPDMSTREEIAVW & $T$ & NLTEARVR \\
\hline XP_001141234.1 (Chimpanzee) & ) AEDPSKKK & R & QRRQRTHFTSQQLQELEATFQRNRYPDMSTREEIAVW & T & NLTEARVR \\
\hline XP_001091288.1 (Monkey) & AEDPSKKK & $\mathrm{R}$ & QRRQRTHFTSQQLQELEATFQRNRYPDMSTREEIAVW & $T$ & NLTEARVR \\
\hline XP_ 851370.1 & TEDPSKKK & R & QRRQRTHFTSQQLQELEATFQRNRYPDMSTREEIAVW & $\mathrm{T}$ & NLTEARVR \\
\hline NP_001091460.1(Cattle) & AEDPSKKK & R & QRRQRTHFTSQQLQELEATFQRNRYPDMSTREEIAVW & T & NLTEARVR \\
\hline NP_001035967.1 (Mouse) & AEDPSKKK & R & QRRQRTHFTSQQLQELEATFQRNRYPDMSTREEIAVW & $\mathrm{T}$ & NLTEARVR \\
\hline NP_001035970.1(Rat) & AEDPSKKK & $\mathbf{R}$ & QRRQRTHFTSQQLQELEATFQRNRYPDMSTREEIAVW & $T$ & NLTEARVR \\
\hline NP_990341.1 & PEDPSKKK & $\mathbf{R}$ & QRRQRTHFTSQQLQELEATFQRNRYPDMSTREEIAVW & $T$ & NLTEARVR \\
\hline NP_571050.1 & NDDPSKKK & R & QRRQRTHFTSQQLQELEATFQRNRYPDMSTREEIAVW & T & NLTEARVR \\
\hline NP_001138130.1 (Fruit fly) & PKNDKKNK & $R$ & QRRQRTHFTSQQLQELEHTFSRNRYPDMSTREEIAMW & $\mathrm{T}$ & NLTEARVR \\
\hline (Mosquito) & NDKKNK & $R$ & QRRQRTHFTSQQLHELEQTFSRNRYPDMSTREEIAMW & & NLTEARVR \\
\hline
\end{tabular}

Figure 4. Multiple alignments of PITX2c protein sequences across species. The altered amino acids of p.R91 and p.T129S are completely conserved evolutionarily among a wide variety of species.

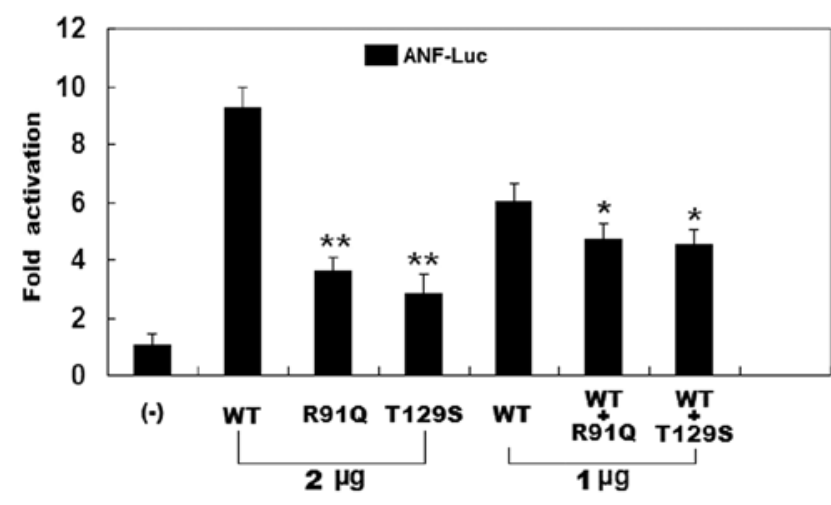

Figure 5. Functional defects associated with PITX2c mutations. Activation of atrial natriuretic factor $(A N F)$ promoter driven luciferase reporter in Chinese hamster ovary (CHO) cells by wild-type PITX2c (WT) or mutant PITX2c (R91Q or T129S), alone or in combination revealed significantly decreased transcriptional activity resulted from mutant proteins. Experiments were performed in triplicate, and the mean \pm standard deviations are shown. ${ }^{* *} \mathrm{P}<0.0005$ and ${ }^{*} \mathrm{P}<0.001$ compared with the same amount $(2 \mu \mathrm{g})$ of wild-type PITX2c.

displayed that the affected amino acids were completely conserved evolutionarily (Fig. 4), indicating that the amino acids are functionally important.

Causative potential of the PITX2c variations. The PITX2c sequence variations of $c .272 \mathrm{G}>\mathrm{A}$ and c.385A $>\mathrm{T}$ were both predicted to be disease-causing by MutationTaster, with the same P-value of 1.000. No SNPs in the altered regions were found in the MutationTaster database. In addition, these 2 amino acid substitutions (p.R91Q and p.T129S) were also predicted to be possibly damaging by PolyPhen-2, with the same scores of 0.995 (sensitivity, 0.68; specificity, 0.97) for p.R91Q and p.T129S.

Functional defect associated with PITX2c mutations. As shown in Fig. 5, the same amounts of wild-type PITX2c (2 $\mu \mathrm{g})$,
Table II. Phenotypic characteristics and status of the PITX2c mutations in the affected family members.

\begin{tabular}{|c|c|c|c|c|c|}
\hline \multicolumn{3}{|c|}{ Subject Information } & \multicolumn{2}{|c|}{ Phenotype } & \multirow{2}{*}{$\begin{array}{r}\text { Genotype } \\
\text { (PITX2c } \\
\text { mutation) }\end{array}$} \\
\hline Identity & Gender & $\operatorname{Age}^{\mathrm{a}}$ & CHD & $\mathrm{AF}$ & \\
\hline \multicolumn{5}{|l|}{ Family 1} & R91Q \\
\hline $\mathrm{I}-1$ & M & $52^{\mathrm{b}}$ & VSD & + & NA \\
\hline II-1 & $\mathrm{F}$ & 31 & VSD & + & $+/-$ \\
\hline II-5 & M & 26 & VSD & - & $+/-$ \\
\hline III-1 & M & 2 & VSD & - & $+/-$ \\
\hline III-3 & $\mathrm{F}$ & 0 & TGA, VSD & - & $+/-$ \\
\hline \multicolumn{5}{|l|}{ Family 2} & T129S \\
\hline I-1 & M & $49^{\mathrm{b}}$ & VSD & - & NA \\
\hline II-1 & M & $0^{\mathrm{b}}$ & TGA, VSD & - & NA \\
\hline II-2 & $\mathrm{F}$ & 25 & VSD & - & $+/-$ \\
\hline III-1 & M & 0 & TGA, VSD & - & $+/-$ \\
\hline
\end{tabular}

F, female; M, male; CHD, congenital heart disease; VSD, ventricular septal defect; TGA, transposition of the great arteries; AF, atrial fibrillation; NA, not available or not applicable. ' + ' indicates the presence of mutation and '-' denotes the absence of mutation. 'Age is presented in years; bage at death.

R91Q-mutant PITX2c (2 $\mu \mathrm{g})$ and T129S-mutant PITX2c ( $2 \mu \mathrm{g})$ activated the $A N F$ promoter by approximately a 9-, 4- and 3 -fold increase, respectively, when compared with the empty plasmid. When the same amount of wild-type PITX2c $(1 \mu \mathrm{g})$ was transfected in combination with mutant PITX2c $(1 \mu \mathrm{g}$ of R91Q-mutant or $1 \mu \mathrm{g}$ of T129S-mutant), the induced activation of the $A N F$ promoter was increased by approximately 5 -fold compared with the empty plasmid. These results indicate that the PITX2c mutants are associated with significantly reduced activation activity compared with their wild-type counterpart. 


\section{Discussion}

The human PITX2c gene maps to chromosome 4q25, coding for a protein of 324 amino acids (58). PITX2c is predominantly expressed in the developing and adult heart and is required for normal cardiovascular development (59). In the present study, 2 novel heterozygous mutations of PITX2c, p.R91Q and p.T129S, were identified in 2 newborns with CHD. The mutant alleles were absent in the 400 reference chromosomes from an ethnically matched control population. Cross-species alignment of PITX2c protein sequences revealed that the altered amino acids were completely conserved evolutionarily. These 2 variations were predicted to be pathogenic by both MutationTaster and PolyPhen-2, and functional analysis demonstrated that the mutants were associated with a significantly reduced transcriptional activity. Therefore, it is likely that functionally compromised PITX2c predisposes to CHD in these mutation carriers.

PITX2 is a member of the paired-like homeobox transcription factor family. To date, 4 distinct PITX2 transcripts, generated by differential mRNA splicing and alternative promoter usage, have been reported, of which PITX2a, PITX2b and PITX2c differ only in their amino-termini and have been identified in humans, mice, chicks, zebrafish and Xenopus, whereas the 4th isoform, PITX2d, which lacks the whole amino-terminal domain and most homeodomains, has only been identified in humans. The unique amino-termini of PITX2a, PITX2b and PITX2c may have an effect on their transcriptional activity in a cell-type and promoter-dependent manner. The homeodomain may recognize and bind to specific DNA sequences (5'-TAATCC-3'), which is responsible for DNA binding and interaction with other transcription factors (60). The PITX2c mutations of p.R91Q and p.T129S identified in the present study are located in the homeodomain, and thus they may be expected to exert an effect on the transcriptional activity of PITX2c by perturbing its DNA binding.

PITX2c is an upstream regulator of multiple target genes expressed in the heart during embryogenesis, including the ANF gene (61). Therefore, the functional characteristics of a PITX2c mutation can be investigated by the assay of the transcriptional activity of the $A N F$ promoter in cells expressing PITX2c mutant in contrast to its wild-type counterpart. In this study, the functional effect of 2 novel PITX2c mutations identified in patients with CHD was characterized by transcriptional activity analysis and the results demonstrated that the mutants were associated with a significantly decreased transcriptional activity on the downstream gene, $A N F$, suggesting that PITX2c loss-of-function mutations are potentially an alternative pathological mechanism of CHD.

The fact that dysfunctional PITX2c confers enhanced susceptibility to CHD has been substantiated in animal models. In mice, PITX2c is expressed specifically in the trabecular and septal myocardium with a strong expression bias in the myocardium associated with endocardial cushions of the atrioventricular canal and outflow tract, which are crucial for cardiac septation (62), and the targeted disruption of the PITX2c gene has been shown to result in embryonic lethality due to cardiovascular defects, including atrial isomerism, ventricular septal defect, double-outlet right ventricle, atrial septal defect and abnormal aortic arch (42). In Xenopus, the knockdown of PITX2c by the use of chemically modified antisense oligonucleotides has ben shown to lead to aberrant cardiac morphology, of which the most commonly observed cardiac deformity was a failure of rightward migration of the outflow tract, occurring in $23 \%$ of embryos injected with the PITX2c antisense oligonucleotides. Other cardiac deformations caused by PITX2c-targeted mRNA interference included anomalies of atrial septation, extracellular matrix restriction, relative atrial-ventricular chamber positioning and restriction of ventricular development (43). These experimental findings highlight an exquisite sensitivity of the developing cardiovascular system to the level of PITX2c.

Notably, mutant PITX2c has been causally linked to lone or familial atrial fibrillation $(53,54)$. In this study, 2 novel PITX2c mutations were identified in 2 families with ventricular septal defect, of which 2 family members also had atrial fibrillation, and 2 family members also had transition of the great arteries. Different genetic backgrounds and epigenetic modifiers may account for the pronounced phenotypic heterogeneity among these mutation carriers.

In conclusion, the current study associates PITX2c lossof-function mutations with transition of the great arteries and ventricular septal defect in humans, which provides additional evidence supporting that the fact that PITX2c plays an important role in cardiovascular development.

\section{Acknowledgements}

The authors are thankful to the participants for their dedication to the study. This study was supported by grants from the National Natural Science Foundation of China (81270161 and 81271927) and the Science and Technology Foundation of the Medical College of Shanghai Jiao Tong University (13XJ10070).

\section{References}

1. Roger VL, Go AS, Lloyd-Jones DM, Benjamin EJ, Berry JD, Borden WB, Bravata DM, Dai S, Ford ES, Fox CS, Fullerton HJ, Gillespie C, Hailpern SM, Heit JA, Howard VJ, Kissela BM, Kittner SJ, Lackland DT, Lichtman JH, Lisabeth LD, Makuc DM, Marcus GM, Marelli A, Matchar DB, Moy CS, Mozaffarian D, Mussolino ME, Nichol G, Paynter NP, Soliman EZ, Sorlie PD, Sotoodehnia N, Turan TN, Virani SS, Wong ND, Woo D and Turner MB; American Heart Association Statistics Committee and Stroke Statistics Subcommittee: Heart disease and stroke statistics-2012 update: a report from the American Heart Association. Circulation 125: e2-e220, 2012.

2. Bang JS, Jo S, Kim GB, Kwon BS, Bae EJ, Noh CI and Choi JY: The mental health and quality of life of adult patients with congenital heart disease. Int J Cardiol 170: 49-53, 2013.

3. Idorn L, Jensen AS, Juul K, Overgaard D, Nielsen NP, Sørensen K, Reimers JI and Søndergaard L: Quality of life and cognitive function in Fontan patients, a population-based study. Int J Cardiol 168: 3230-3235, 2013.

4. Kröönström LA, Johansson L, Zetterström AK, Dellborg M, Eriksson $\mathrm{P}$ and Cider A: Muscle function in adults with congenital heart disease. Int J Cardiol 170: 358-363, 2014.

5. Lu JC, Cotts TB and Dorfman AL: Diastolic function and patientreported quality of life for adolescents and adults with repaired tetralogy of Fallot: a tissue Doppler study. Pediatr Cardiol 33: 618-624, 2012.

6. Broberg CS, Van Woerkom RC, Swallow E, Dimopoulos K, Diller GP, Allada G and Gatzoulis MA: Lung function and gas exchange in Eisenmenger syndrome and their impact on exercise capacity and survival. Int J Cardiol 171: 73-77, 2014.

7. Donofrio MT, Duplessis AJ and Limperopoulos C: Impact of congenital heart disease on fetal brain development and injury. Curr Opin Pediatr 23: 502-511, 2011. 
8. Rushani D, Kaufman JS, Ionescu-Ittu R, Mackie AS, Pilote L, Therrien J and Marelli AJ: Infective endocarditis in children with congenital heart disease: cumulative incidence and predictors. Circulation 128: 1412-1419, 2013.

9. Passarella G, Trifirò G, Gasparetto M, Moreolo GS and Milanesi O: Disorders in glucidic metabolism and congenital heart diseases: detection and prevention. Pediatr Cardiol 34: 931-937, 2013.

10. Martínez-Quintana E, Rodríguez-González F and Nieto-Lago V: Subclinical hypothyroidism in grown-up congenital heart disease patients. Pediatr Cardiol 34: 912-917, 2013.

11. Zomer AC, Vaartjes I, van der Velde ET, de Jong HM, Konings TC, Wagenaar LJ, Heesen WF, Eerens F, Baur LH, Grobbee DE and Mulder BJ: Heart failure admissions in adults with congenital heart disease; risk factors and prognosis. Int J Cardiol 168: 2487-2493, 2013.

12. Ueda A, Adachi I, McCarthy KP, Li W, Ho SY and Uemura H: Substrates of atrial arrhythmias: histological insights from patients with congenital heart disease. Int J Cardiol 168 2481-2486, 2013

13. Perry JC: Sudden cardiac death and malignant arrhythmias: the scope of the problem in adult congenital heart patients. Pediatr Cardiol 33: 484-490, 2012

14. Olson EN: Gene regulatory networks in the evolution and development of the heart. Science 313: 1922-1927, 2006.

15. Lee LJ and Lupo PJ: Maternal smoking during pregnancy and the risk of congenital heart defects in offspring: a systematic review and metaanalysis. Pediatr Cardiol 34: 398-407, 2013.

16. Ackerman C, Locke AE, Feingold E, Reshey B, Espana K, Thusberg J, Mooney S, Bean LJ, Dooley KJ, Cua CL, Reeves RH, Sherman SL and Maslen CL: An excess of deleterious variants in VEGF-A pathway genes in Down-syndrome-associated atrioventricular septal defects. Am J Hum Genet 91: 646-659, 2012.

17. Tan HL, Glen E, Töpf A, Hall D, O'Sullivan JJ, Sneddon L, Wren C, Avery P, Lewis RJ, ten Dijke P, Arthur HM, Goodship JA and Keavney BD: Nonsynonymous variants in the SMAD6 gene predispose to congenital cardiovascular malformation. Hum Mutat 33: 720-727, 2012.

18. Soemedi R, Wilson IJ, Bentham J, Darlay R, Töpf A, Zelenika D, Cosgrove C, Setchfield K, Thornborough C, Granados-Riveron J, Blue GM, Breckpot J, Hellens S, Zwolinkski S, Glen E, Mamasoula C, Rahman TJ, Hall D, Rauch A, Devriendt K, Gewillig M, O' Sullivan J, Winlaw DS, Bu'Lock F, Brook JD, Bhattacharya S, Lathrop M, Santibanez-Koref M, Cordell HJ, Goodship JA and Keavney BD: Contribution of global rare copynumber variants to the risk of sporadic congenital heart disease. Am J Hum Genet 91: 489-501, 2012

19. Sanchez-Castro M, Gordon CT, Petit F, Nord AS, Callier P, Andrieux J, Guérin P, Pichon O, David A, Abadie V, Bonnet D, Visel A, Pennacchio LA, Amiel J, Lyonnet S and Le Caignec C: Congenital heart defects in patients with deletions upstream of SOX9. Hum Mutat 34: 1628-1631, 2013.

20. Wu M, Li Y, He X, Shao X, Yang F, Zhao M, Wu C, Zhang C and Zhou L: Mutational and functional analysis of the BVES gene coding region in Chinese patients with non-syndromic tetralogy of Fallot. Int J Mol Med 31: 899-903, 2013

21. Aoki Y, Niihori T, Banjo T, Okamoto N, Mizuno S, Kurosawa K, Ogata T, Takada F, Yano M, Ando T, Hoshika T, Barnett C, Ohashi H, Kawame H, Hasegawa T, Okutani T, Nagashima T, Hasegawa S, Funayama R, Nagashima T, Nakayama K, Inoue S, Watanabe Y, Ogura T and Matsubara Y: Gain-of-function mutations in RIT1 cause Noonan syndrome, a RAS/MAPK pathway syndrome. Am J Hum Genet 93:173-180, 2013.

22. Chang SW, Mislankar M, Misra C, Huang N, Dajusta DG, Harrison SM, McBride KL, Baker LA, Garg V. Genetic abnormalities in FOXP1 are associated with congenital heart defects. Hum Mutat 34: 1226-1230, 2013.

23. Schott JJ, Benson DW, Basson CT, Pease W, Silberbach GM, Moak JP, Maron BJ, Seidman CE and Seidman JG: Congenital heart disease caused by mutations in the transcription factor NKX2-5. Science 281:108-111, 1998.

24. Wang J, Xin YF, Liu XY, Liu ZM, Wang XZ and Yang YQ: A novel NKX2-5 mutation in familial ventricular septal defect. Int J Mol Med 27: 369-375, 2011

25. Xie WH, Chang C, Xu YJ, Li RG, Qu XK, Fang WY, Liu X and Yang YQ: Prevalence and spectrum of Nkx2.5 mutations associated with idiopathic atrial fibrillation. Clinics (Sao Paulo) 68: 777-784, 2013

26. Huang RT, Xue S, Xu YJ, Zhou M and Yang YQ: A novel NKX2.5 loss-of-function mutation responsible for familial atrial fibrillation. Int J Mol Med 31: 1119-1126, 2013.
27. Garg V, Kathiriya IS, Barnes R, Schluterman MK, King IN, Butler CA, Rothrock CR, Eapen RS, Hirayama-Yamada K, Joo K, Matsuoka R, Cohen JC and Srivastava D: GATA4 mutations cause human congenital heart defects and reveal an interaction with TBX5. Nature 424: 443-447, 2003.

28. Wang J, Fang M, Liu XY, Xin YF, Liu ZM, Chen XZ, Wang XZ, Fang WY, Liu X and Yang YQ: A novel GATA4 mutation responsible for congenital ventricular septal defects. Int J Mol Med 28: 557-564, 2011.

29. Liu XY, Wang J, Zheng JH, Bai K, Liu ZM, Wang XZ, Liu X, Fang WY and Yang YQ: Involvement of a novel GATA4 mutation in atrial septal defects. Int J Mol Med 28: 17-23, 2011.

30. Yang YQ, Gharibeh L, Li RG, Xin YF, Wang J, Liu ZM, Qiu XB Xu YJ, Xu L, Qu XK, Liu X, Fang WY, Huang RT, Xue S and Nemer G: GATA4 loss-of-function mutations underlie familial tetralogy of fallot. Hum Mutat 34: 1662-1671, 2013.

31. Yang YQ, Wang J, Wang XH, Wang Q, Tan HW, Zhang M, Shen FF, Jiang JQ, Fang WY and Liu X: Mutational spectrum of the GATA5 gene associated with familial atrial fibrillation. Int J Cardiol 157: 305-307, 2012.

32. Jiang JQ, Li RG, Wang J, Liu XY, Xu YJ, Fang WY, Chen XZ, Zhang W, Wang XZ and Yang YQ: Prevalence and spectrum of GATA5 mutations associated with congenital heart disease. Int J Cardiol 165: 570-573, 2013

33. Wei D, Bao H, Liu XY, Zhou N, Wang Q, Li RG, Xu YJ and Yang YQ: GATA5 loss-of-function mutations underlie tetralogy of fallot. Int J Med Sci 10: 34-42, 2013.

34. Wang XH, Huang CX, Wang Q, Li RG, Xu YJ, Liu X, Fang WY and Yang YQ: A novel GATA5 loss-of-function mutation underlies lone atrial fibrillation. Int J Mol Med 31: 43-50, 2013.

35. Zheng GF, Wei D, Zhao H, Zhou N, Yang YQ and Liu XY: A novel GATA6 mutation associated with congenital ventricular septal defect. Int J Mol Med 29: 1065-1071, 2012.

36. Wang J, Luo XJ, Xin YF, Liu Y, Liu ZM, Wang Q, Li RG, Fang WY, Wang XZ and Yang YQ: Novel GATA6 mutations associated with congenital ventricular septal defect or tetralogy of fallot. DNA Cell Biol 31: 1610-1617, 2012.

37. Yang YQ, Wang XH, Tan HW, Jiang WF, Fang WY and Liu X: Prevalence and spectrum of GATA6 mutations associated with familial atrial fibrillation. Int J Cardiol 155: 494-496, 2012

38. Li J, Liu WD, Yang ZL and Yang YQ: Novel GATA6 loss-offunction mutation responsible for familial atrial fibrillation. Int $\mathrm{J}$ Mol Med 30: 783-790, 2012.

39. Huang RT, Xue S, Xu YJ and Yang YQ: Somatic mutations in the GATA6 gene underlie sporadic tetralogy of Fallot. Int J Mol Med 31: 51-58, 2013.

40. Bruneau BG: The developmental genetics of congenital heart disease. Nature 451: 943-948, 2008.

41. McCulley DJ and Black BL: Transcription factor pathways and congenital heart disease. Curr Top Dev Biol 100: 253-277, 2012.

42. Liu C, Liu W, Palie J, Lu MF, Brown NA and Martin JF: Pitx2c patterns anterior myocardium and aortic arch vessels and is required for local cell movement into atrioventricular cushions. Development 129: 5081-5091, 2002.

43. Dagle JM, Sabel JL, Littig JL, Sutherland LB, Kolker SJ and Weeks DL: Pitx2c attenuation results in cardiac defects and abnormalities of intestinal orientation in developing Xenopus laevis. Dev Biol 262: 268-281, 2003

44. Bamforth SD, Bragança J, Farthing CR, Schneider JE, Broadbent C, Michell AC, Clarke K, Neubauer S, Norris D, Brown NA, Anderson RH and Bhattacharya S: Cited2 controls left-right patterning and heart development through a NodalPitx2c pathway. Nat Genet 36: 1189-1196, 2004.

45. Li Q, Pan H, Guan L, Su D and Ma X: CITED2 mutation links congenital heart defects to dysregulation of the cardiac gene VEGF and PITX2C expression. Biochem Biophys Res Commun 423: 895-899, 2012

46. Mommersteeg MT, Brown NA, Prall OW, de Gier-de Vries C, Harvey RP, Moorman AF and Christoffels VM: Pitx2c and $\mathrm{Nkx} 2-5$ are required for the formation and identity of the pulmonary myocardium. Circ Res 101: 902-909, 2007.

47. Galli D, Domínguez JN, Zaffran S, Munk A, Brown NA and Buckingham ME: Atrial myocardium derives from the posterior region of the second heart field, which acquires left-right identity as Pitx2c is expressed. Development 135: 1157-1167, 2008.

48. Lozano-Velasco E, Chinchilla A, Martínez-Fernández S, Hernández-Torres F, Navarro F, Lyons GE, Franco D and Aránega AE: Pitx2c modulates cardiac-specific transcription factors networks in differentiating cardiomyocytes from murine embryonic stem cells. Cells Tissues Organs 194: 349-362, 2011. 
49. Liu C, Liu W, Lu MF, Brown NA and Martin JF: Regulation of left-right asymmetry by thresholds of Pitx $2 \mathrm{c}$ activity. Development 128: 2039-2048, 2001.

50. Clauss S and Kääb S: Is Pitx2 growing up? Circ Cardiovasc Genet 4: 105-107, 2011

51. Yuan F, Zhao L, Wang J, Zhang W, Li X, Qiu XB, Li RG, Xu YJ, Xu L, Qu XK, Fang WY and Yang YQ: PITX2c loss-of-function mutations responsible for congenital atrial septal defects. Int J Med Sci 10: 1422-1429, 2013.

52. Wang J, Xin YF, Xu WJ, Liu ZM, Qiu XB, Qu XK, Xu L, Li X and Yang YQ: Prevalence and spectrum of PITX2c mutations associated with congenital heart disease. DNA Cell Biol 32: 708-716, 2013.

53. Zhou YM, Zheng PX, Yang YQ, Ge ZM and Kang WQ: A novel PITX2c loss-of-function mutation underlies lone atrial fibrillation. Int J Mol Med 32: 827-834, 2013.

54. Yang YQ, Xu YJ, Li RG, Qu XK, Fang WY and Liu X: Prevalence and spectrum of PITX2c mutations associated with familial atrial fibrillation. Int J Cardiol 168: 2873-2876, 2013.

55. Strungaru MH, Footz T, Liu Y, Berry FB, Belleau P, Semina EV, Raymond V and Walter MA: PITX2 is involved in stress response in cultured human trabecular meshwork cells through regulation of SLC13A3. Invest Ophthalmol Vis Sci 52: 7625-7633, 2011.

56. Footz T, Idrees F, Acharya M, Kozlowski K and Walter MA: Analysis of mutations of the PITX2 transcription factor found in patients with Axenfeld-Rieger syndrome. Invest Ophthalmol Vis Sci 50: 2599-2606, 2009.
57. Acharya M, Lingenfelter DJ, Huang L, Gage PJ and Walter MA: Human PRKC apoptosis WT1 regulator is a novel PITX2interacting protein that regulates PITX2 transcriptional activity in ocular cells. J Biol Chem 284: 34829-34838, 2009.

58. Semina EV, Reiter R, Leysens NJ, Alward WL, Small KW, Datson NA, Siegel-Bartelt J,Bierke-Nelson D, Bitoun P, Zabel BU, Carey JC and Murray JC: Cloning and characterization of a novel bicoid-related homeobox transcription factor gene, RIEG, involved in Rieger syndrome. Nat Genet 14: 392-399, 1996.

59. Kirchhof P, Kahr PC, Kaese S, Piccini I, Vokshi I, Scheld HH, Rotering H, Fortmueller L, Laakmann S, Verheule S, Schotten U, Fabritz L and Brown NA: PITX2c is expressed in the adult left atrium, and reducing Pitx $2 \mathrm{c}$ expression promotes atrial fibrillation inducibility and complex changes in gene expression. Circ Cardiovasc Genet 4: 123-133, 2011.

60. Simard A, Di Giorgio L, Amen M, Westwood A, Amendt BA and Ryan AK: The Pitx 2c N-terminal domain is a critical interaction domain required for asymmetric morphogenesis. Dev Dyn 238: 2459-2470, 2009.

61. Ganga M, Espinoza HM, Cox CJ, Morton L, Hjalt TA, Lee Y and Amendt BA: PITX2 isoform-specific regulation of atrial natriuretic factor expression: synergism and repression with $\mathrm{Nkx} 2.5$. J Biol Chem 278: 22437-22445, 2003.

62. Furtado MB, Biben C, Shiratori H, Hamada H and Harvey RP: Characterization of Pitx $2 \mathrm{c}$ expression in the mouse heart using a reporter transgene. Dev Dyn 240: 195-203, 2011. 